\title{
EFEKTIVITAS PEMBELAJARAN DARING MATA PELAJARAN BIOLOGI SELAMA PANDEMI COVID-19 DI SMA IT AL HUDA WONOGIRI
}

\author{
PENDI SETYAWAN \\ SMAIT Al Huda Wonogiri \\ e-mail: pendisetyawan146@gmail.com
}

\begin{abstract}
ABSTRAK
Penelitian ini bertujuan untuk mendeskripsikan (1) efektivitas pelaksanaan pembelajaran daring mata pelajaran Biologi menggunakan googlemeet selama masa pandemi Covid-19 di SMAIT Al Huda Wonogiri dan (2) kendala yang dihadapi. Penelitian ini dilakukan di SMAIT Al Huda Wonogiri menggunakan pendekatan deskriptif analitik. Data dari penelitian ini diperoleh melalui survei yang disebarkan kepada peserta didik melalui aplikasi Whatsapps dalam bentuk googleform. Hasil penelitian yang diperoleh bahwa pembelajaran daring di SMAIT Al Huda Wonogiri cukup efektif dimana peserta didik merasa senang dengan pembelajaran daring mata pelajaran Biologi, guru dan peserta didik berinteraksi dengan baik, bahan ajar yang disajikan guru cukup berkualitas, peserta didik mudah mengikuti pembelajaran daring, peserta didik mudah dalam mengajukan pertanyaan, dan materi pembelajaran dapat tersampaikan dengan baik oleh guru. Meskipun demikian, kendala selama pembelajaran tetap ada diantaranya gangguan sinyal atau layanan internet yang menyebabkan suara guru yang kurang jelas terdengar oleh peserta didik atau sering putusnya koneksi jaringan, keterbatasan perangkat gawai dan kuota.
\end{abstract}

Kata Kunci: Efektivitas, Pembelajaran daring, Biologi

\section{ABSTRACT}

This study aims to describe (1) the effectiveness of implementing online learning for Biology subjects using googlemeet during the Covid-19 pandemic at SMAIT Al Huda Wonogiri and (2) the obstacles faced. This research was conducted at SMAIT Al Huda Wonogiri using a descriptive analytic approach. The data from this study were obtained through a survey distributed to students through the Whatsapps application in the form of a google form. The results obtained that online learning at SMAIT Al Huda Wonogiri is quite effective where students feel happy with online learning for Biology subjects, teachers and students interact well, teaching materials presented by teachers are of sufficient quality, students are easy to follow online learning, students It is easy for students to ask questions, and learning materials can be delivered well by the teacher. However, there are still obstacles during learning, including signal interference or internet service which causes the teacher's voice to be less clear to students or frequent network connections, limitations of gadgets and quotas.

Keywords: Effectiveness, Online Learning, Biology

\section{PENDAHULUAN}

Pandemi covid-19 bukan hanya memperburuk perekonomian, akan tetapi juga mengganggu kegiatan pendidikan di Indonesia. Pandemi ini memaksa kita, sebagai warga Indonesia untuk tetap tinggal dirumah, melarang untuk berkerumun, melaksanakan pembatasan sosial dan menjaga jarak fisik, memakai masker dan selalu mencuci tangan agar dapat memutus mata rantai penyebaran covid-19. Kegiatan pembelajaran di sekolah dengan tatap muka langsung tidak dapat dilaksanakan untuk mencegah penularan virus ini. Kondisi peserta didik dan guru yang tidak dapat bertemu secara langsung inilah yang membuat pembelajaran harus dilakukan secara daring atau belajar dari rumah (BDR).

Pembelajaran daring disarankan oleh Kementerian Pendidikan dan Kebudayaan yang diperkuat dengan keluarnya surat edaran Nomor 4 tahun 2020 tentang Pelaksanaan Kebijakan Pendidikan dalam Masa Darurat Penyebaran Corona Virus Disease (Covid-19) yang diperkuat dengan SE Sekjen Nomor 15 tahun 2020 tentang Pedoman Pelaksanaan BDR selama masa 
darurat. Ada tiga hal kebijakan pembelajaran yang dilaksanakan secara daring. Yaitu yang pertama, pembelajaran daring/jarak jauh untuk memberi pengalaman belajar yang bermakna, tanpa terbebani tuntutan menuntaskan seluruh capaian kurikulum untuk kenaikan kelas maupun kelulusan. Kedua, dapat difokuskan pada pendidikan kecakapan hidup, antara lain mengenai pandemi Covid-19. Ketiga, aktivitas dan tugas pembelajaran dapat bervariasi antar siswa, sesuai minat dan kondisi masing-masing, termasuk mempertimbangkan kesenjangan akses/fasilitas belajar di rumah (Kemdikbud, 2020).

Salah satu aplikasi yang digunakan dalam pembelajaran daring yaitu Google meet. Penggunaan google meet dalam pembelajaran pada peserta didik tahun 2020 ini digunakan dalam pembelajaran dengan memadukan aplikasi lain yaitu whatsapp group. Melalui group ini guru dan peserta didik dapat berkomunikasi dengan baik dan sebagai salah satu alternative media pembelajaran daring jika sewaktu-waktu ada kendala. Aplikasi Google meet mampu menampung 250 orang dalam setiap teleconference. Pembelajaran menggunakan google meets ini, guru tidak hanya bisa melihat dokumen belajar peserta didik saja tetapi juga dapat melakukan: presentasi, menayanglan mateti, dan merekamnya. Pada proses belajar, peserta didik menyalakan video sehingga guru bisa mengontrol kehadiran dan aktifitas peserta didik di dalam kelas.

\section{METODE PENELITIAN}

Jenis penelitian yang digunakan pendekatan deskriptif analitik. Tujuan penelitian ini adalah menggambarkan pembelajaran daring yang diselenggarakan di SMAIT Al Huda Wonogiri sebagai upaya memberikan hak belajar kepada peserta didik selama masa pandemi Covid-19. Pembelajaran daring dalam penelitian ini adalah pembelajaran yang menggunakan media-media pembelajaran yang dapat diakses menggunakan layanan internet khususnya pertemuan daring dengan menggunakan aplikasi Google meet. Penelitian dilakukan dengan mengadakan survey kepada peserta didik mengenai pelaksanaan pembelajaran daring di SMAIT Al Huda Wonogiri. Survey disebarkan dalam bentuk Google meet yang diberikan kepada peserta didik melalui pesan WhatsApps. Sebanyak 106 peserta didik yang telah memberikan respon terhadap survei yang telah disebarkan.

\section{HASIL DAN PEMBAHASAN}

Hasil

Hasil penelitian ditemukan beberapa fakta dari hasil analisis jawaban responden terkait pembelajaran daring BIOLOGI di SMAIT Al Huda Wonogiri.

\section{a. Kondisi Emosional Peserta Didik}

Selama terjadinya pandemi Covid-19, peserta didik melaksanakan belajar dari rumah. Hal ini berdasarkan Surat Edaran Kementerian Pendidikan dan Kebudayaan Nomor 15 tahun 2020 tentang pedoman penyelenggaraan belajar dari rumah dalam masa darurat penyebaran Corona Virus Disease (COVID-19). Berdasarkan hasil angket yang diberikan pada responden, perasaan peserta didik saat belajar dari rumah dapat dilihatpada gambar 1 .

Dalam konteks pembelajaran menyenangkan, peserta didik lebih diarahkan untuk memiliki motivasi tinggi dalam belajar dengan menciptakan situasi yang menyenangkandan menggembirakan. Perasaan peserta didik saat pembelajaran daring Biologi dapat dilihat pada gambar 2.

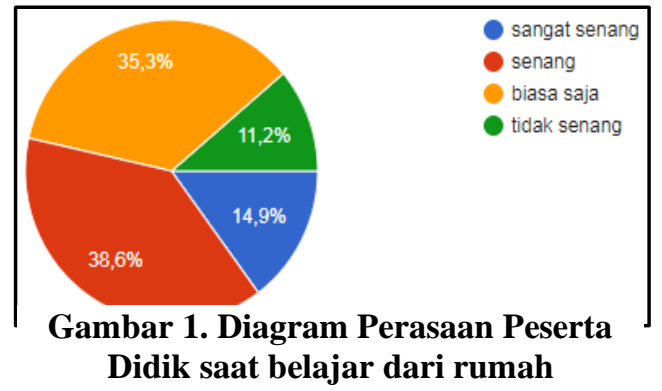
Didik saat belajar dari rumah

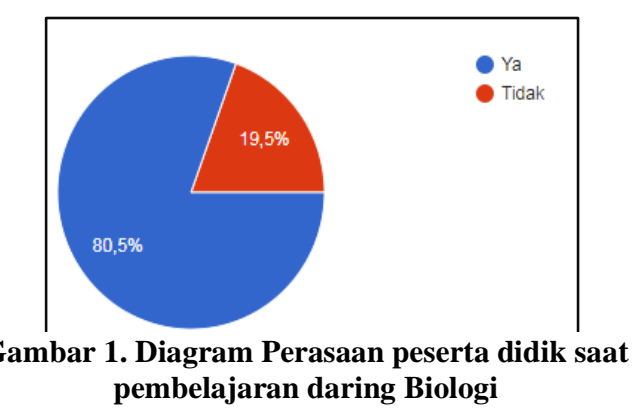




\section{b. Mutu Pembelajaran Daring Mata Pelajaran Biologi}

Salah satu indikator efektivitas pembelajaran menurut Slavin (2009) adalah mutu pembelajaran. Mutu pembelajaran dapat dilihat dari penyajian infomasi (bahan ajar, penyampaian materi), aktivitas gurudan peserta didik dan kemudahan pembelajaran.

Berdasarkan hasil kuesioner, masih banyak peserta didik yang menyatakan bahwa pembelajaran daring cukup mudah untuk dilakukan. (gambar 3). Dalam pembelajaran tentunya terjadi interaksi baik antara guru dan peserta didik, ataupun antar sesama peserta didik. Sebagian besar pesertadidik menyatakan bahwa terjadi interaksi yang baik antar guru dan peserta didik (gambar 4).

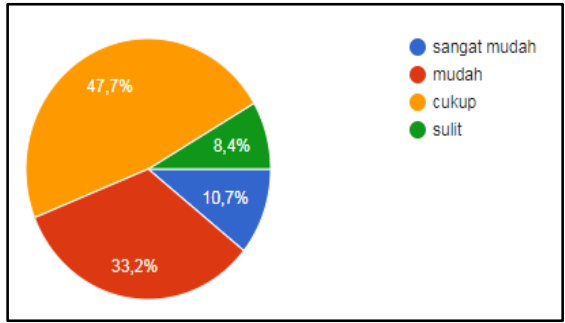

Gambar 3. Kemudahan pembelajaran daring

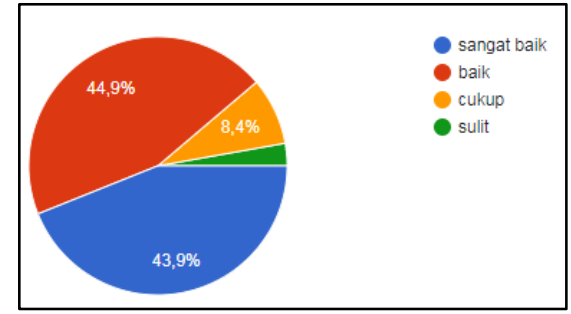

Gambar 4. Interaksi Guru dan Peserta Didik

Salah satu bentuk interaksi antara guru dan peserta didik adalah mengajukan pertanyaan. Berdasarkan hasil kuesioner, mengajukan pertanyaan selama pembelajaran daring termasuk sangat mudah (gambar 5).

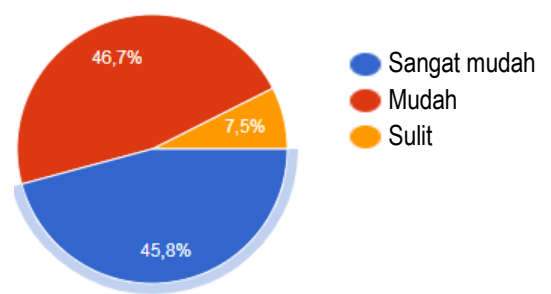

\section{Gambar 5. Kemudahan Mengajukan Pertanyaan Dalam Pembelajaran Daring}

Dalam proses pembelajaran terdapat proses penyampaian informasi atau materi pelajaran.. Berdasarkan hasil kuesioner yang diberikan kepada peserta didik, sebanyak $81,8 \%$ menyatakan bahwa selama pembelajaran daring materi pelajaran dapat tersampaikan dengan baik oleh guru ke peserta didik. (Gambar 6).

Proses pembelajaran memerlukan bahan ajar yang berguna untuk membantu guru dalam melaksanakan pembelajaran. Pada pembelajaran daring pun, bahan ajar tetap dibutuhkan dalam proses pembelajaran terutama bahan ajar berbasis teknologi seperti slide, video, multimedia, dan lain sebagainya. Berdasarkan hasil kuesioner menyatakan bahwa bahan ajar yang disajikan guru kepada peserta didik cukup berkualitas (gambar 7).

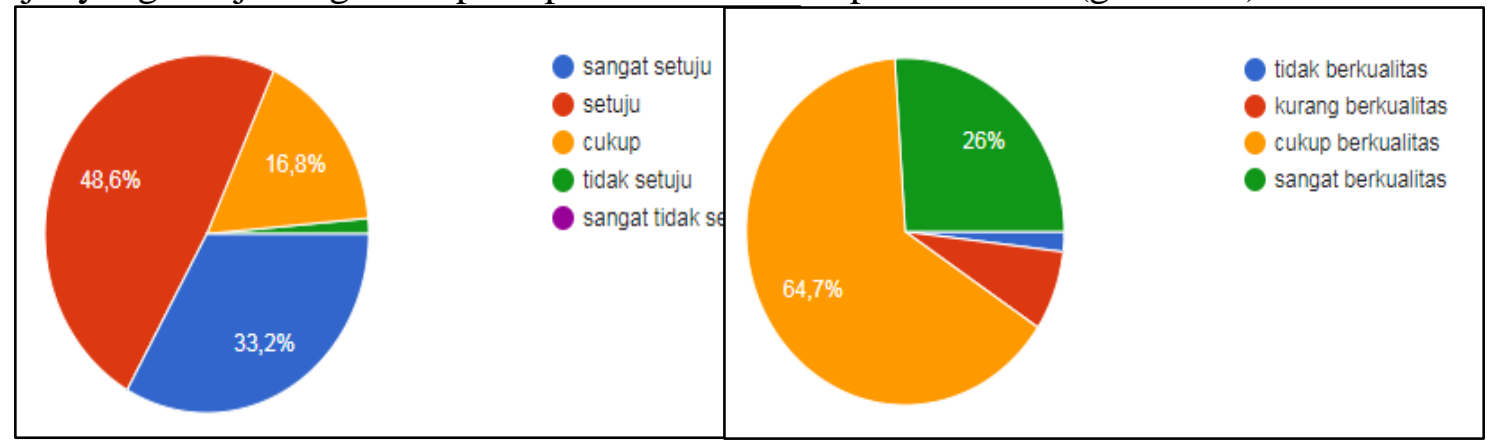

Gambar 6. Penyampaian Materi Pembelajaran 


\section{c. Pembelajaran Daring}

Terdapat kekurangan dari pembelajaran daring yang telah dilaksanakan. Berdasarkan hasil dari kuesioner yang diisi oleh peserta didik menyatakan bahwa sebagian besar peserta didik mengalami gangguang sinyal kemudian diikuti suara guru yang kurang jelas terdengar ke peserta didik, kemudian media pembelajaran khususnya video tidak dapat terdengar dengan jelas suaranya (audionya).

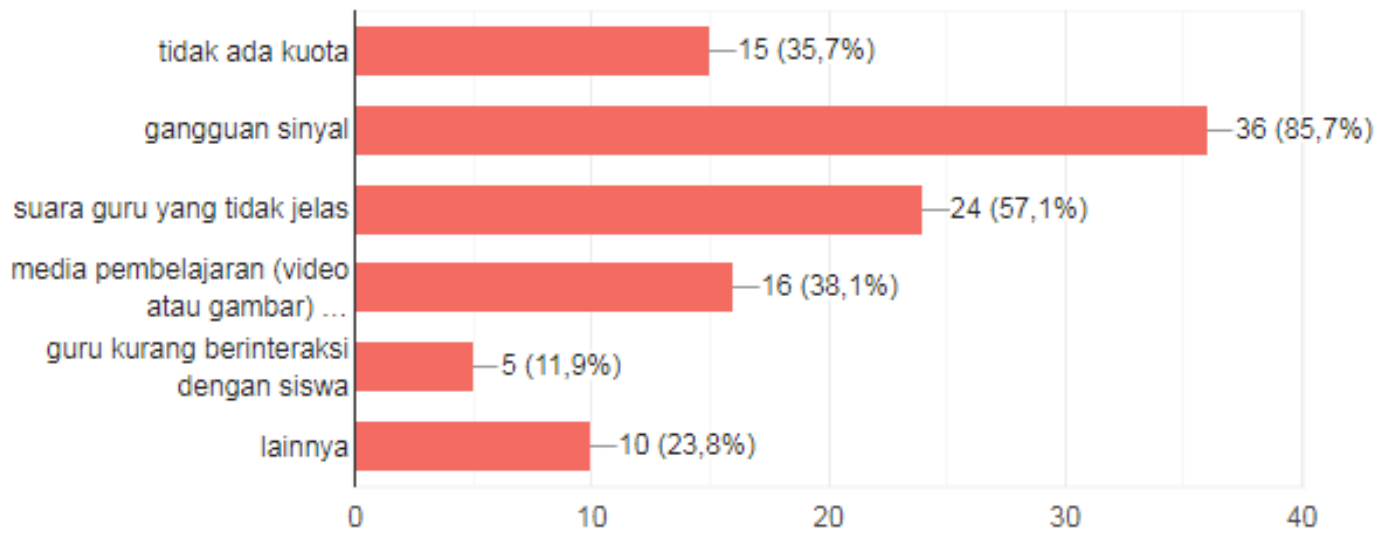

\section{Pembahasan}

\section{a. Kondisi Emosional Peserta Didik}

Proses pembelajaran baik tatap muka maupun pembelajaran daring hendaknya selalu mempertimbangkan kondisi emosional peserta didik. Hal ini karena kondisi emosional peserta didik saat belajar sangat besar pengaruhnya terhadap keberhasilan belajar (Ilmi Al Idrus, Damayanti, \& Ermayani, 2020). Dari hasil penelitian diperoleh bahwa sebagian besar peserta didik SMAIT Al Huda Wonogiri yang mengikuti pembelajaan daring dari rumah menyatakan senang belajar dari rumah. Hal ini diperkuat dengan pernyataan peserta didik bahwa mereka dapat melakukan pembelajaran di rumah atau tempat lainnya dan peserta didik tidak perlu bersiap-siap di pagi hari untuk berangkat ke sekolah. Feri \& Rusdi (2020) dalam penelitiannya juga menyimpulkan bahwa pada dasarnya peserta didik senang belajar dengan sistem pembelajaran daring. namun tetap ada beberapa dari peserta didik masih terkendala pada fasilitas internet dan biaya yang perlu dikeluarkan.

Dari hasil kuesioner yang diberikan pada peserta didik mengenai perasaan peserta didik saat belajar Biologi, lebih dari setengah peserta didik yang mengisi kuesioner menyatakan senang saat belajar Biologi.

\section{b. Mutu Pembelajaran daring Mata Pelajaran Biologi}

Pembelajaran daring Mata Pelajaran Biologi merupakan adaptasi pembelajaran di masa pandemi Covid-19 ini sehingga peserta didik juga harus beradaptasi dengan keadaan. Adaptasi peserta didik diantaranya harus melek teknologi. Dari hasil kuesioner, ternyata peserta didik menyatakan cukup mudah menggunakan teknologi digital dalam mengikuti pembelajaran daring. Hal ini dikarenakan peserta didik merupakan generasi zoomers (Gen Z) dimana generasi ini merupakan generasi sosial yang tumbuh dengan akses internet dan teknologi digital portabel sejak usia muda. Meskipun tidak semua dari gen $\mathrm{Z}$ ini melek digital. Gen $\mathrm{Z}$ yang hidup dalam dua alam (fisik \& maya) tak membedakan realitas diantara keduanya. Melihat dunia maya sama pentingnya dengan dunia fisik (Wijoyo, H., dkk, 2020). Dari pernyataan Wijoyo, dkk (2020) berarti peserta didik melihat pembelajaran daring sama dengan pembelajaran tatap muka.

Pembelajaran tatap muka didominasi dengan interaksi langsung antara guru dengan peserta didik, dan antar peserta didik. Pembelajaran daring juga mengedepankan interaksi namun dilakukan melalui perantara teknologi digital. Berdasarkan hasil kuesioner, peserta didik menyatakan bahwa dalam pembelajaran daring terjadi interaksi antara guru dan peserta didik dengan baik. Komunikasi guru dapat berupa menyampaikan materi pembelajaran 
kepada peserta didik, menyapa peserta didik, menanyakan kabar, membimbing peserta didik dalam berdoa sebelum memulai pembelajaran, dan sebagainya. Sementara komunikasi peserta didik dapat berupa kegiatan bertanya atau menjawab pertanyaan guru (diskusi), menyapa guru, menyapa teman-teman lainnya, berdiskusi dengan peserta didik lainnya, berbagi informasi melalui pembelajaran daring.

Salah satu bentuk interaksi antara guru dan peserta didik adalah mengajukan pertanyaan atau berdiskusi. Hasil kuesioner yang direspon oleh peserta didik menyatakan bahwa peserta didik sangat mudah dalam mengajukan pertanyaan dalam pembelajaran daring. Dalam hal ini, tidak ada hambatan komunikasi dalam menyampaikan argumen atau mengajukan pertanyaan meskipun melalui perantaraan teknologi digital.

Bentuk interaksi lainnya yaitu penyampaian materi pembelajaran oleh guru. Berdasarkan hasil kuesioner, lebih dari $81,8 \%$ peserta didik menyatakan bahwa materi pembelajaran Biologi dapat tersampaikan dengan baik ketika pembelajaran daring. Salah satu tugas pokok guru adalah menyampaikan materi pembelajaran dengan baik, untuk itu diperlukan guru harus mempersiapkan materi dengan menarik sehingga mendapatkan perhatian dari peserta didik. Guru dapat membuat bahan ajar berupa slide power point dengan penampilan yang menarik dan atraktif, menampilkan video yang berkaitan dengan materi pembelajaran, atau aplikasi pembelajaran yang dapat membuat peserta didik tidak bosan dalam pembelajaran daring.

Berdasarkan hasil kuesioner yang diberikan kepada peserta didik, bahan ajar yang disajikan oleh guru dalam pembelajaran daring mata pelajaran Biologi cukup berkualitas. Dalam penelitian ini, peneliti merujuk pada penilai bahan ajar yang kedua dimana peserta didik menilai kualitas bahan ajar berdasarkan hal yang langsung tampak. Bahan ajar yang digunakan oleh guru Biologi di SMAIT Al Huda Wonogiri selama masa pembelajaran daring yaitu slide power point (yang didalamnya berisi materi, gambar dan video yang menunjang), video youtube, dan aplikasi digital diantaranya simulasi laboratorium virtual. Berdasarkan hal yang langsung tampak pada bahan ajar, peserta didik memberikan respon bahwa kualitas bahan ajar yang disampaikan oleh guru Biologi di SMAIT Al Huda Wonogiri cukup berkualitas.

Berdasarkan indikator efektivitas yang direspon oleh peserta didik yaitu kondisi emosional peserta didik yang menyatakan senang ketika pembelajaran daring Biologi, dan mutu pembelajaran daring Biologi yang baik maka dapat disimpulkan bahwa pembelajaran daring Mata Pelajaran Biologi di SMAIT Al Huda Wonogiri berjalan cukup efektif dalam memberikan pembelajaran kepada peserta didik dan mengurangi tingkat kerumunan massa guna mencegah penularan virus Covid-19.

\section{c. Kendala Pembelajaran Daring Biologi}

Kendala jaringan internet ini sebenarnya menjadi masalah yang utama dalam pembelajaran daring karena beberapa penelitian juga menyebutkan bahwa jaringan internet yang tidak baik menjadi masalah dalam pembelajaran daring (Alchamdani, dkk, 2020). Demikian juga Sadikin \& Hamidah (2020) dalam penelitiannya menyatakan bahwa tantangan pembelajaran daring adalah ketersediaan layanan internet. Sebagian peserta didik mengakses internet menggunakan layanan seluler dan sebagian kecil menggunakan layanan WiFi. Peserta didik juga menyatakan bahwa suara guru kurang jelas, fasilitas handphone dan internet yang kurang memadai, waktu pembelajaran daring yang singkat.

Tantangan lainnya adalah ketika lokasi antara guru dan peserta didik yang terpisah saat melaksanakan pembelajaran menyebabkan guru tidak bisa mengawasi secara langsung kegiatan belajar peserta didik. Guru tidak dapat mengamati peserta didik benar-benar hadir dalam pembelajaran atau fokus pada aktivitas lainnya.

\section{KESIMPULAN}

1. Pembelajaran daring mata pelajaran Biologi di SMAIT Al Huda Wonogiri ditinjau dari indikator efektivitas pembelajaran yang dikemukakan oleh Slavin (2009) yaitu kondisi 
emosional peserta didik, dan mutu pembelajaran daring maka pembelajaran daringMata pelajaran Biologi di SMAIT Al Huda Wonogiri termasuk cukup efektif.

2. Adapun kendala-kendala yang dihadapi oleh peserta didik SMAIT Al Huda Wonogiri dalam pembelajaran daring mata Pelajaran Biologi antara lain gangguan sinyal jaringan internet sehingga menyebabkan suara atau audio pembicara terputus-putus, fasilitas gawai dan kuota/layanan internet yang tidak memadai, media pembelajaran yang kurang menarik, interaksi searah dari guru, dan lainnya.

\section{DAFTAR PUSTAKA}

Alchamdani, dkk. (2020). The Impact of COVID19 Pandemic on Online Learning Process In The College at Southeast Sulawesi. Jurnal Kesehatan Lingkungan, Vol. 12, No. 1.

Andalsia Malyana. (2020). Pelaksanaan Pembelajaran Daring dan Luring Dengan Metode Bimbingan Berkelanjutan Pada Guru Sekolah Dasar di Teluk Betung Utara Bandar Lampung. Pedagogia : Jurnal Ilmiah Pendidikan Dasar Indonesia.

Angga Wiratama, N. (2020). Penerapan Googlemeet Dalam Perkuliahan Daring Mahasiswa PGSD Pada Mata Kuliah Konsep dasar PKN SD Saat Pandemi Covid-19. JTIEE, Vol. 4 No. 2.

Ariska W. (2011). Kualitas Bahan Ajar Dan Pemanfaatan Bahan Ajar Berupa Buku Paket Di SMKN 2 Yogyakarta Mata Pelajaran Produktif Program Keahlian Teknik Instalasi Tenaga Listrik Kelas X. Skripsi.

Feri, P. dan Rusdi. (2020). Respon Siswa Dalam Pembelajaran Online Selama Pandemi. Social Lanscape Journal

Fitrinai, N. (2020). Efektivitas Pembelajaran Daring Selama Pandemi COVID-19. Universitas Pendidikan Indonesia. Skripsi.

Handojo, A., Chandra, R., dan Andjarwirawan, J. (2009). Aplikasi Video Conference Dengan Kemampuan Beroperasi Pada IPV4 dan IPV6. Seminar Nasional Aplikasi Teknologi Informasi 2009. Yogyakarta.

Ika Handarini, O. dan Sri Wulandari, S. (2020). Pembelajaran Daring Sebagai Upaya Study From Home (SFH) Selama Pandemi Covid19. Jurnal Pendidikan Administrasi Perkantoran (JPAP) Vol. 8, No. 3.

Ilmi Al idrus, S.F, damayanti, P.S, dan Ermayani. (2020). Pengembangan Kecerdasam Emosional Peserta Didik Di Sekolah Dasar Melalui Pendidikan Karakter. PENDASI: Jurnal Pendidikan Dasar Indonesia, Vol. 4 No. 1.

Khusniyah, N. dan Hakim, L. (2019). Efektifitas Pembelajaran Berbasis Daring : Sebuah Bukti Pada Pembelajaran Bahasa Inggris. Jurnal Tatsqif : Jurnal Pemikiran dan Penelitian Pendidikan, Vol. 17, No. 1.

Kuntarto, E. (2017). Keefektifan Model Pembelajaran Daring Dalam Perkuliahan Bahasa Indonesia di Perguruan Tinggi. Journal Indonesian Language Education and Literature, Vo. 3, No. 1.

Kurniasari, A., Setyo Putro, F., dan Adi Putra, D. (2020). Analisis Efektivitas Pelaksanaan Belajar Dari Rumah (BDR) Selama Pandemi COVID-19. Jurnal Review Pendidikan Dasar: Jurnal Kajian Pendidikan dan Hasil Penelitian, Vol.6 No. 3.

Mega Berliana Yolandasari. (2020). Efektivitas Pembelajaran daring Dalam Pembelajaran Bahasa Indonesia Di Kelas II.A MI Unggulan Miftahul Huda Tumang Cepogo Boyolali Tahun Pelajaran 2019/2020. Skripsi.

Mustakim. (2020). Efektivitas Pembelajaran Daring Menggunakan Media Online Selama Pandemi COVID-19 Pada Mata Pelajaran Matematika. Al asma : Journal of Islamic Education, Vol. 2, No. 1

Rakhwati, dkk. (2020). Pembelajaran Berbasis Google Classroom, Googlemeet, dan Zoom Guru SMP Negeri 2 Batubara. BERNAS: Jurnal Pengabdian kepada Masyarakat. Vol. 1, No.4. pp 410-416. 
Sawitri, D. (2020). Penggunaan Googlemeet Untuk Work from Home di era pandemi Coronavirus disease 2019 (Covid-19). Jurnal prioritas : Jurnal Pengabdian Masyarakat, Vol. 02, No. 1.

Sobron A.N, Bayu, Rani dan Meidawati. (2019). Persepsi Siswa Dalam Studi Pengaruh Daring Learning Terhadap Minat Belajar IPA. Scaffolding: Jurnal Pendidikan Islam dan Multikulturalisme, Vol: 1 No. 2.

Sofyana, L., dan Rozaq, A. (2019). Pembelajaran Daring Kombinasi Berbasis Whatsapp Pada Kelas Karyawan Prodi Teknik Informatika Universitas PGRI Madiun. Jurnal Nasional Pendidikan Teknik Informatika, Vol. 8, No. 1.

Widayati, S. (2020). Respon Mahasiswa Pada Proses Pembelajaran Mata Kuliah Daring. CEJ: Child Education Journal.

Wijoyo, H., dkk. (2020). Generasi Z dan Revousi Industri 4.0. Penerbit CV. Pena Persada. Jawa Tengah. 